\title{
KARAKTERISTIK IBU HAMIL KEKURANGAN ENERGI KRONIK (KEK) DI PUSKESMAS PAJANGAN BANTUL
}

\author{
Widyawati $^{1}$, Sholaikhah Sulistyoningtyas ${ }^{2}$ \\ ${ }^{1,2}$ Universitas Aisyiyah Yogyakarta, sholaikhahtyas@unisayogya.ac.id
}

\section{INFORMASI ARTIKEL:}

Riwayat Artikel:

Tanggal di Publikasi: Desember 2020

Kata kunci:

Karakteristik ibu hamil

KEK
A B S T R A K

KEK merupakan kekurangan energi atau asupan nutrisi yang berlangsung lama. KEK sering terjadi pada ibu hamil, berdasarkan data Dinas Kesehatan Kabupaten Bantul prevalensi ibu hamil KEK di Puskesmas Pajangan tahun 2016 sebesar 16,20\%, tahun 2017 sebesar 14,91\% dan tahun 2018 sebesar 13,42\%.Dampak KEK pada ibu hamil yaitu anemia, pendarahan, berat badan ibu tidak bertambah secara normal, terkena penyakit infeksi serta menjadi penyebab tidak langsung kematian ibu.Dampak pada bayi yaitu berat badan lahir, angka kematian perinatal, keadaan kesehatan perinatal, dan pertumbuhan bayi setelah kelahiran.Tujuan penelitian ini adalah diketahuinya gambaran karakteristik ibu hamil kekurangan energi kronis di Puskesmas Pajangan tahun 2018.Metode penelitian ini adalah deskriptif. Penelitian ini dilakukan di wilayah Puskesmas Pajangan Kabupaten Bantul.Populasi adalah seluruh ibu hamil yang mengalami kekurangan energi kronis (KEK) di Puskesmas Pajangan tahun 2018 sebanyak 84 orang.Sampel menggunakan teknik total sampling yaitu seluruh populasi dijadikan sampel sebanyak 84 orang. Hasil penelitian didapatkan bahwa sebagian besar usia ibu hamil yang mengalami KEK adalah ibu yang berusia tidak beresiko sebanyak 74 orang $(88 \%)$, paritas ibu hamil yang mengalami KEK adalah primigravida sebanyak 50 orang $(59,5 \%)$, pendidikan ibu hamil yang mengalami KEK adalah ibu dengan pendidikan sedang sebanyak 55 orang $(65,5 \%)$, ibu hamil yang mengalami KEK adalah ibu yang bekerja sebanyak 47 orang (56 \%).Kesimpulan penelitian ini bahwa ibu hamil yang mengalami KEK adalah ibu yang berusia tidak beresiko, primigravida, pendidikan sedang dan ibu yang bekerja.Diharapkan penelitian ini dapat digunakan sebagai bahan informasi agar masyarakat lebih memperhatikan status gizi ibu dan meningkatkan asupan zat gizi pada ibu hamil. 


\section{PENDAHULUAN}

Indikator kesejahteraan suatu bangsa salah satunya diukur dengan angka kematian ibu. Menurut Survei Angka Sensus (Supas) tahun 2015, angka kematian ibu di Indonesia sebesar 305 per 100.000 kelahiran hidup (Kementrian Kesehatan Republik Indonesia, 2019). Lima penyebab utama kematian ibu antara lain perdarahan, infeksi, eklampsi, partus lama, dan komplikasi abortus. Sedangkan penyebab tidak langsung kematian ibu antara lain anemia, Kekurangan Energi Protein (KEP), dan Kekurangan Energi Kalori (KEK) (Ari Sulistyawati, 2012).

Di Indonesia berdasarkan data Riskesdas tahun 2018 prevalensi ibu hamil yang mengalami KEK sebesar 17,3 \%. Program Pemerintah di Pusat Kesehatan Masyarakat (Puskesmas) berusaha memantau status gizi ibu hamil dengan kunjungan antenatal minimal 4 kali selama kehamilan, pengisian Kartu Menuju Sehat (KMS) ibu hamil. Pemerintah melakukan pemberian makanan tambahan (MT) pada ibu hamil (Kemenkes, 2017).

Data profil kesehatan provinsi DIY tahun 2017 menunjukkan prevalensi ibu hamil yang menderita KEK di DIY tahun 2015 adalah 9,11\% dan meningkat pada tahun 2016 yaitu sebesar 10,39 \% dan kembali naik menjadi $10,70 \%$ pada tahun 2017. Pada penelitian sebelumnya yang dilakukan oleh Aprianti (2017), karakteristik ibu hamil sebagian besar mempunyai usia antara 20-35 tahun sebanyak 88,9\%, berpendidikan lulus SMA yaitu sebanyak $66,7 \%$, mempunyai riwayat multigravida sebanyak $55,6 \%$, kehamilan pertama sebanyak $41,7 \%$, dan tidak bekerja sebanyak $72,2 \%$.
Berdasarkan Keputusan Menteri Kesehatan Republik Indonesia nomor 369 tahun 2007 tentang standar profesi bidan mengenai intervensi ibu hamil dengan KEK, dapat dilakukan dengan cara melakukan rujukan ke petugas tenaga gizi serta berkolaborasi untuk membantu memonitoring serta mengevaluasi asupan pemberian makanan dan kenaikan berat badan.Upaya lainnya dalam menanggulangi masalah dan mencegah dampak dari kurang energi kronis pada ibu hamil yaitu mengusahakan agar ibu hamil memeriksakan kehamilan secara rutin sejak hamil muda untuk mendeteksi secara dini kejadian kurang energi kronis, dan penyuluhan tentang asupan nutrisi yang dibutuhkan ibu hamil (Tempali, 2017). Selain itu untuk mengatasi kekurangan gizi pada ibu hamil KEK pemerintah juga menyelenggarakan Pemberian Makanan Tambahan (PMT) Pemulihan (Ditjen Bina Gizi dan Kesehatan Ibu dan Anak Kementrian Kesehatan RI, 2012).

Berdasarkan data dari DinKes Bantul tahun 2018 menunjukkan bahwa prevalensi ibu hamil KEK sebesar 9,79 \%, dengan prevalensi tertinggi di Puskesmas Dlingo II sebesar 24,49 \% dan prevalensi terendah di Puskesmas Kretek sebesar 2,69\%. Sedangkan prevalensi bumil KEK di Puskesmas Pajangan yaitu tahun 2016 sebesar 16,20\%, tahun 2017 sebesar 14,91\% dan tahun 2018 sebesar 13,42\%. Adapun target ibu hamil yang mengalami KEK yaitu $10 \%$ dari seluruh ibu hamil. Dari data prevalensi ibu hamil KEK di Puskesmas Pajangan pada periode tiga tahun terakhir menunjukkkan bahwa prevalensinya mengalami penurunan, namun masih berada diatas target yang diharapkan.Oleh sebab itu penelitian 
tentang tentang Gambaran Karakteristik Ibu Hamil Kekurangan Energi Kronis (KEK) di Puskesmas Pajangan menjadi penting untuk dilakukan.

\section{METODE PENELITIAN}

Rancangan penelitian yang digunakan dalam penelitian ini adalah deskriptif. Variabel yang digunakan adalah variabel tunggal yaitu karakteristik ibu hamil kekurangan energi kronik (KEK) yang meliputi umur, paritas, tingkat pendidikan dan jenis pekerjaan.

Populasi dalam penelitian ini adalah seluruh ibu hamil yang mengalami kekurangan energi kronis (KEK) di Puskesmas Pajangan tahun 2018 sebanyak 84 orang.Adapun pengambilan sampel dalam penelitian ini yaitu menggunakan teknik total sampling, yaitu seluruh populasi dijadikan sampel sebanyak 84 orang.

Peneliti mengumpulkan data ibu hamil yang mengalami KEK dari buku register ibu hamil kemudian mengidentifikasi karakteristiknya dengan melihat catatan pada status ibu hamil di rekam medis.

\section{HASIL DAN PEMBAHASAN}

Tabel 1. Distribusi Frekuensi Umur

Ibu Hamil Kekurangan energi

Kronik di Puskesmas Pajangan Bantul

\begin{tabular}{ll}
\hline Umur & Frekuensi \\
\hline Umur $<20$ th & 3 \\
\hline Umur 20-35 th & 74 \\
Umur $>35$ th & 7 \\
\hline Jumlah & 84 \\
\hline
\end{tabular}

Sumber: Data Sekunder diolah tahun 2020
Berdasarkan tabel 1 dari hasil penelitian di atas menunjukkan bahwa mayoritas umur ibu hamil yang mengalami KEK adalah ibu yang berumur tidak beresiko sebanyak 74 orang $(88 \%)$.

Tabel 2. Distribusi Frekuensi Paritas

Ibu Hamil Kekurangan Energi

Kronik di Puskesmas Pajangan

Bantul Yogyakarta tahun 2018

\begin{tabular}{lll}
\hline Paritas & Frekuensi & Presentase \\
\hline Primigravida & 50 & $59,5 \%$ \\
Multigravida & 33 & $39,3 \%$ \\
Grandemultigravida & 1 & $1,2 \%$ \\
\hline Jumlah & 84 & $100 \%$ \\
\hline
\end{tabular}

Sumber: Data Sekunder diolah tahun 2020

Berdasarkan tabel 2 dari hasil penelitian di atas menunjukkan bahwa mayoritas paritas ibu hamil yang mengalami KEK adalah primigravida sebanyak 50 orang $(59,5 \%)$.

Tabel 3. Distribusi Frekuensi Pendidikan Ibu Hamil Kekurangan

Energi Kronik di Puskesmas Pajangan Bantul Yogyakarta tahun 2018

\begin{tabular}{llc}
\hline Pendidikan & Frekuensi & Presentase \\
Rendah & 20 & $23,8 \%$ \\
Sedang & 55 & $65,5 \%$ \\
Tinggi & 9 & $10,7 \%$ \\
\hline Jumlah & 84 & $100 \%$ \\
\hline Sumber: Data Sekunder diolah tahun 2020
\end{tabular}

Tabel 4. Distribusi Frekuensi Pekerjaan Ibu Hamil Kekurangan

Energi Kronik di Puskesmas Pajangan Bantul Yogyakarta tahun 2018

\begin{tabular}{llc}
\hline Pekerjaan & Frekuensi & Prosentase \\
Bekerja & 47 & $56 \%$ \\
Tidak bekarja & 37 & $44 \%$ \\
\hline Jumlah & 84 & $100 \%$ \\
\hline
\end{tabular}

Sumber: Data Sekunder diolah tahun 2020 
Berdasarkan table 4 dari hasil penelitian di atas menunjukkan bahwa mayoritas ibu hamil yang mengalami KEK adalah ibu yang bekerja sebanyak 47 orang $(56 \%)$.

\section{Karakteristik ibu hamil KEK berdasarkan umur ibu}

Hasil penelitian ini menunjukkan bahwa ibu hamil KEK di Puskesmas Pajangan dengan umur tidak beresiko (20-35 tahun) sebanyak 74 orang lebih banyak dari ibu hamil KEK dengan umur yang beresiko $(<20$ tahun $>35$ tahun) sebanyak 10 orang.

Semakin muda dan semakin tua umur seseorang ibu yang sedang hamil berpengaruh terhadap kebutuhan gizi yang diperlukan.Ibu hamil pada umur yang terlalu muda atau masih remaja cenderung memiliki berat badan kurang dari normal dan ibu akan mengalami penambahan berat badan yang kurang selama kehamilan.Sedangkan untuk umur tua perlu energi yang besar juga karena fungsi organ yang melemah dan diharuskan untuk bekerja maksimal. Sehingga umur yang paling baik adalah lebih dari 20 tahun dan kurang dari 35 tahun, dengan harapan gizi ibu hamil akan lebih baik (Siti Fitriani, 2018).

Hasil penelitian yang dilakukan di Puskesmas Pajangan sejalan dengan hasil penelitian Sukmawati (2016) menunjukkan bahwa dari 42 ibu hamil KEK di Puskesmas Pembangunan, Kabupaten Garut sebanyak 22 responden (52.4\%) berada di rentang usia yang tidak beresiko (20 tahun - 35 tahun), sedangkan ibu hamil KEK dengan usia beresiko sebanyak 22 orang $(47,6 \%)$.
Penelitian lain yang sejalan adalah penelitian oleh Siti Fitriani (2018) menunjukkan bahwa sebagian besar ibu hamil yang mengalami Kekurangan Energi Kronik (KEK) di Wilayah Kerja Puskesmas Sukaratu Kabupaten Tasikmalaya sebagian besar ada pada kategori umur 20-35 tahun yaitu sebanyak $74,2 \%$.

\section{Karakteristik ibu hamil KEK berdasarkan paritas ibu}

Hasil penelitian ini menunjukkan bahwa karakteristik ibu hamil yang mengalami Kekurangan Energi Kronis terbanyak pada primigravida yaitu sebanyak 50 orang ( $59,5 \%)$, sedangkan pada multigravida sebanyak 33 orang $(39,3 \%)$, dan grandemultigravida sebanyak 1 orang $(1,2 \%)$.Hal ini terjadi karena ibu hamil dengan primipara mempunyai risiko yang cukup tinggi mengalami KEK.Seorang ibu yang melahirkan multipara mempunyai risiko mengalami KEK pada kehamilan berikutnya, apabila tidak memperhatikan kebutuhan nutrisi.Karena selama hamil zat - zat gizi bukan hanya dibutuhkan ibu saja melainkan untuk janin yang dikandungnya. Paritas 2-3 merupakan paritas yang paling aman ditinjau dari sudut kematian maternal, paritas 1 dan paritas tinggi (lebih dari 3) mempunyai angka kematian maternal lebih tinggi (Prawirohardjo, 2014).

Hasil penelitian ini sejalan dengan penelitian Siti Fitriani (2018) menunjukkan bahwa ibu hamil yang mengalami Kekurangan Energi Kronis (KEK) di Wilayah Kerja Puskesmas Sukaratu, Kabupaten Tasikmalaya mayoritas pada kategori primipara yaitu sebanyak 84 orang 
$(86,6 \%)$, sedangkan sebagian kecil ada pada kategori paritas multipara sebanyak 13 orang $(13,4 \%)$.

\section{Karakteristik ibu hamil KEK berdasarkan tingkat pendidikan ibu}

Pada penelitian ini menunjukkan bahwa karakteristik ibu hamil yang mengalami Kekurangan Energi Kronis terbanyak yaitu ibu yang memiliki pendidikan sedang (SMA, MA, SMK, MAK atau bentuk lain yang sederajat) sebanyak 55 orang $(65,5 \%)$ sedangkan dengan pendidikan rendah yaitu sebanyak 20 orang $(23,8 \%)$ dan pendidikan tinggi sebanyak 9 orang $(10,7 \%)$.Hal ini kemungkinan disebabkan karena kelompok ibu tingkat pendidikan rendah dan kelompok ibu tingkat pendidikan tinggi memiliki kemungkinan yang sama menderita KEK.Pengetahuan dan kemampuan seseorang dipengaruhi oleh latar belakang pendidikan.Makin tinggi pendidikan seseorang, maka makin mudah baginya untuk menerima informasi (Siti Fitriani, 2018).

Penelitian ini sejalan dengan penelitian yang dilakukan oleh Puspitasari (2011) menunjukkan bahwa ibu hamil Kekurangan Energi Kronis (KEK) di Kecamatan Wonosalam,Kabupaten Demak sebagian besar responden mempunyai tingkat pendidikan SMA (tingkat pendidikan sedang) yaitu sebanyak 15 responden (50\%).

Penelitian lain yang sejalan adalah penelitian yang dilakukan oleh Eka Aprianti (2017) menunjukkan bahwa ibu hamil Kekurangan Energi Kronis (KEK) di Puskesmas Kasihan I, Bantul, Yogyakarta sebagian besar berpendidikan lulus SMA yaitu sebanyak $66,7 \%$.

Penelitian Siti Fitriani (2018) juga sejalan dengan penelitian yang dilakukan di Puskesmas Pajangan yaitu menunjukkan bahwa ibu hamil yang mengalami Kekurangan Energi Kronik (KEK) di Wilayah Kerja Puskesmas Sukaratu Kabupaten Tasikmalaya sebagian besar tingkat pendidikan ada pada kategori menengah yaitu sebanyak 53 orang $(54,6 \%)$.

\section{Karakteristik ibu hamil KEK berdasarkan pekerjaan ibu}

Pada penelitian ini menunjukkan bahwa karakteristik ibu hamil yang mengalami Kekurangan Energi Kronis terbanyak pada ibu bekerja yaitu 47 orang (56\%), sedangkan yang tidak bekerja sebanyak 37 orang (44\%).Hal ini kemungkinan disebabkan karena setiap aktifitas memerlukan energi, maka apabila semakin banyak aktifitas yang dilakukan, energi yang dibutuhkan juga semakin banyak.Namun pada seorang ibu hamil kebutuhan zat gizi berbeda karena zat-zat gizi yang dikonsumsi selain untuk aktifitas/ kerja zat-zat gizi juga digunakan untuk perkembangan janin yang ada dikandungan ibu hamil tersebut.Ibu hamil yang harus melakukan pekerjaan fisik berat biasanya memiliki status gizi yang rendah apabila tidak diimbangi dengan asupan makanan dalam jumlah yang cukup dan bergizi (Fatonah, 2016).

Hasil penelitian yang dilakukan di Puskesmas Pajangan sejalan dengan hasil penelitian Sukmawati (2016) menunjukkan bahwa dari 42 ibu hamil KEK di Puskesmas Pembangunan, Kabupaten Garut 
sebagian besar mempunyai pekerjaan yang berat yaitu sebanyak 29 responden $(69,0 \%)$ dan hampir sebagian dari responden memiliki pekerjaan yang ringan yaitu sebanyak 13 orang (31.0\%).

\section{KESIMPULAN DAN SARAN}

Kesimpulan yang dapat peneliti sampaikan adalah:

1. Karakteristik ibu hamil yang mengalami kekurangan Energi kronis dengan usia beresiko sebayak 10 orang $(11,9 \%)$, sedangkan yang berusia tidak beresiko sebanyak 74 orang $(88,1 \%)$.

2. Karakteristik ibu hamil yang mengalami Kekurangan Energi Kronis primigravida sebanyak 50 orang $(59,5 \%)$, multigravida sebanyak 33 orang (39,3\%), sedangkan grandemultigravida sebanyak 1 orang $(1,2 \%)$.

3. Karakteristik ibu hamil Kekurangan Energi Kronis dengan pendidikan rendah yaitu sebanyak 20 orang (23,8\%), pendidikan sedang sebanyak 55 orang $(65,5 \%)$ dan pendidikan tinggi sebanyak 9 orang $(10,7 \%)$.

4. Karakteristik ibu hamil Kekurangan Energi Kronis yang bekerja yaitu sebanyak 47 orang (56 \%), sedangkan yang tidak bekerja sebanyak 37orang (44\%).

Saran yang dapat peneliti sampaikan adalah:

1. Masyarakat

Hasil penelitian ini hendaknya digunakan sebagai bahan informasi dan agar masyarakat lebih memperhatikan status gizi ibu dan meningkatkan asupan zat gizi

2. Tenaga Kesehatan di Puskesmas Pajangan, Bantul
Hasil penelitian ini dapat dijadikan sebagai salah satu sumber informasi tentang status gizi ibu hamil yang mengalami Kekurangan Energi Kronis (KEK) sehingga petugas kesehatan dapat meningkatkan program pemerintah untuk menurunan angka kejadian ibu hamil yang mengalami KEK.Dan disarankan agar KIA mempunyai data ibu hamil sesuai karakteristiknya,sehingga akan mempermudah dalam pengelompokan data serta mempermudah apabila akan dilakukan penelitian.

3. Mengambil Kebijakan di Puskesmas Pajangan

Puskesmas yang merupakan salah satu fasilitas pelayanan kesehatan diharapkan dapat menentukan kebijakan sebagai upaya meningkatkan pencegahan terhadap masalah status gizi ibu hamil (tidak hanya pada masa kehamilan tetapi juga pada saat pra nikah).Hasil penelitian ini dapat digunakan sebagai salah satu sumber data dalam perencanaan upaya kesehatan masyarakat terutama dalam perencanaan program gizi dan program KIA.

4. Peneliti Selanjutnya

Hasil penelitian ini diharapkan sebagai masukan dan bahan pertimbangan untuk peneliti selanjutnya dalam melakukan penelitian pada status gizi ibu hamil dengan memasukan faktor-fakor lain yang berpengaruh terhadap kejadian KEK pada ibu hamil.

\section{DAFTAR PUSTAKA}

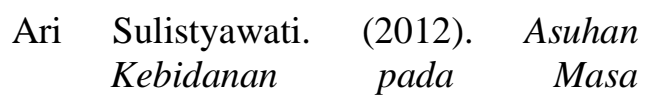


Kehamilan. Jakarta: Salemba Medika.

Arsy Prawita. (2015). Survei Intervensi Ibu Hamil Kurang Energi Kronik (KEK).

http://journal.unpad.ac.id/jsk_ikm larticle/viewFile/12492/5688.

Depkes, R. (2015). PMT. Jakarta.

Dinas Kesehatan DIY. (2017). Profil Kesehatan. Yogyakarta.

Ditjen Bina Gizi dan Kesehatan Ibu Anak Kemenkes. (2012). Panduan Penyelenggaraan Pemberian Makanan Tambahan Pemulihan bagi Balita Gizi Kurang dan Ibu Hamil KEK. Jakarta.

Eka Aprianti. (2017). GAMBARAN KEJADIAN KEKURANGAN ENERGI KRONIS. http://repository.unjaya.ac.id/id/ep rint $/ 2347$.

Fatonah, M. (2016). Gizi dan Kesehatan untuk Ibu Hamil Kajian Teori dan Aplikasinya. Jakarta: Erlangga.

Kemenkes. (2017). Juknis Pemberian Makanan Tambahan. Jakarta.

Kementrian Kesehatan Republik Indonesia. (2019, Februari Jum'at). Direktorat Jenderal Kesehatan Masyarakat. Retrieved Mei Senin, 2020, from Direktorat Jenderal Kesehatan Masyarakat: http://www.kesmas.kemkes.go.id/ portal/konten/ rilisberita/021517-di-rakesnas-2019 dirjen-kesmas-paparkan-strategipenurunan-aki-dan-neonatal

Kementrian Kesehatan RI. (2015). Pedoman Teknis Pemantauan Status Gizi. Jakarta.

Pedoman Proses Asuhan Gizi
Puskesmas. Jakarta.

Marmi. (2013). Gizi dalam Kesehatan Reproduksi. yogyakarta: Pustaka Pelajar.

Notoatmodjo. (2014). Metodologi Penelitian Kesehatan. Jakarta: Rineka Cipta.

Pengurus Pusat Ikatan Bidan Indonesia. (2016). buku Acuan Midwifery Update. Jakarta.

Prawirohardjo. (2014). Ilmu Kebidanan. Jakarta: Yayasan Bina Pustaka.

Pusat Penelitian dan Pengembangan Gizi dan Makanan, Depkes RI. (2009). Risiko Kurang Energi Kronis (KEK) pada Ibu Hamil di Indonesia. Gizi Indon 2009, 32(2):128-138.

Puspitasari. (2011). Gambaran Karakteristik Ibu Hamil yang Menderita KEK di Kecamatan Wonosalam Kabupaten Demak. Semarang: Fakultas Ilmu Keperawatan dan Kesehatan, Universitas Muhammadiyah Semarang Kedungmundu Raya No.22 50727, Semarang, Indonesia.

Seksi Gizi Dinas Kesehatan DIY. (2018). Peta Situasi Gizi DIY Tahun 2017. Yogyakarta. 